\title{
Sports Outfitters' Marketing Strategies: A Comparative Exploratory Study in the U.S. and Canada
}

\author{
Lise Heroux \\ Department of Marketing and Entrepreneurship, School of Business and Economics, State University of New York, USA
}

Copyright@2017 by authors, all rights reserved. Authors agree that this article remains permanently open access under the terms of the Creative Commons Attribution License 4.0 International License

\begin{abstract}
The outdoor/sports outfitter industry comprises primarily of independent businesses engaged in selling a diverse array of sporting and athletic goods for fitness and exercise, golfing, camping, fishing, winter sports, shooting, racket sports, kayaking and other sports. The successful marketing strategy of outdoor/sports outfitters requires the identification of a target market and development of a marketing mix (product/service, place, price and promotion) that will best satisfy the needs of this target market. This research was conducted to investigate the marketing strategies implemented by outfitters to meet the needs of consumers. A census of the 20 outfitters in the contiguous regions of Quebec and New York/Vermont was visited by observers. Systematic observations were compiled for each establishment. More similarities than differences were found. Sports Outfitters in both regions have well-developed product/service strategies, and personal selling strategies, but weaker promotion strategies with respect to advertising. The Quebec sports outfitters have better location and establishment design strategies than Vermont/New York establishments, while the latter have better pricing strategies. American retailers can benefit from the benchmark provided by Canadian stores with respect to location, while Canadian stores can learn from the pricing strategies of American stores. Improvement in promotion initiatives is needed in both regions.
\end{abstract}

Keywords Marketing, Sports, Outfitters, Canada, United States

\section{Introduction}

The sporting and athletic goods manufacturing industry comprises of establishments primarily engaged in manufacturing a diverse array of sporting and athletic goods for fitness and exercise, golfing, camping, fishing, winter sports, shooting, racket sports, and other sports. Because there are few barriers to entry, the industry is characterized by many firms that vary in size and product specialization, and that recognize that brand loyalty plays an important role in their success [1]. Sales and profits in the sports and sports outfitter industry are consistently in an upward trend, even in economic downturns when other types of retailers suffer [2]. As Canadian and American consumers have become more health conscious in general, their purchases of sporting goods, sports apparel and healthy foods have gone up. According to Forbes [3], the global sports apparel market is expected to grow at a rate of $4 \%$ to reach $\$ 178$ billion by 2019. The leading players in this market based on 2012 revenue are Adidas ( $\$ 8.2$ billion), Nike ( $\$ 6.3$ billion), Puma ( $\$ 1.5$ billion), Under Armour (\$1.38 billion), Lulu Lemon Athletica (\$1.37 billion), Asics ( $\$ 470$ million).

\section{Literature Review}

Gold [4] suggests that several socio-economic criteria influence the market demand in this industry. Because sporting and athletic goods are leisure products, and leisure is primarily a matter of individual preferences, market demand is subject to changing tastes and popular trends. Furthermore, the industry must compete against dissimilar industries that also produce leisure products, such as music, books, video games. Finally, economic conditions, demographics, weather conditions, and the pricing of substitute and complementary goods also affect the market demand. Health and fitness are often top priorities for Canadian and American consumers targeted by the sport and sport outfitter industry. As a result, big name shoe retailers such as Nike and Foot Locker have seen dramatic increases in revenue in recent years [2].

Canadians are moving away from organized sports to informal sports activity in their leisure time [5]. From 1992 to 2005, participation in active leisure increased for exercise, sports, outdoor expeditions, cycling, walking and jogging. Winter temperature in Canada is conducive to skiing, snowboarding, snowshoeing and other winter sporting events. Participation in sports outside an organized setting is highly concentrated in about 20 sports led by golf, ice hockey, swimming, soccer, basketball, baseball, volleyball, skiing 
and cycling [6]. Those most likely to participate in active leisure are those individuals with more leisure time, such as women, more highly educated and higher-income individuals, and older Canadians who are looking to stay healthy and active through their retirement [5]. Consumers who once used to exercise in cotton clothing, now insist on high-tech, sweat-resistant fabrics. Runners want running shoes that are lightweight and fitting [2]. Whether it is going to the gym or going on a run outdoors, people are investing in their bodies more now than ever before, and they want to look good and be healthy [7].

Understanding the participation motives, as well as needs and wants, of an athlete can prove beneficial to companies like Nike when designing a new product for their customers. Rohm et al. [8] segmented the population of runners into four segments:

1. Healthy Joggers: run for physical and mental fitness, while running relatively the fewest miles.

2. Social Competitors: run to remain social and be competitive.

3. Actualized Athletes: who have relatively high motivations for self-esteem.

4. Devotees: claim they run because they are addicted to the activity.

Global Marketing Strategy (GMS) suggests that markets can be segmented cross-nationally. Ko et al. [9] find the existence of four psychographic cross-market segments in the sportswear industry: Fashion Leaders, Conspicuous Fashion Consumers, Sensational Seekers, and Sociable Followers. These four segments can be targeted separately by the sportswear industry.

Consumers with an interest in sports are of two types, participants and spectators. With the increasing competition among sports organizations for the discretionary dollars of consumers, competition for new and existing customers is forcing organizations to rethink methods for targeting their fan base [10]. Busch et al. [11] looked at the impact of a favorite athlete on brand loyalty for sporting goods. They found that women tended to have more old school ideals than men, and that the more old school a particular individual was, the less their favorite athlete influenced their brand loyalty. More specifically, the more females believe that professional athletes should be responsible role models, the more their favorite athlete influences their switching behavior.

Gender differences are apparent in the ways that user image varies as a function of brand and co-brand for sports apparel [12]. Brands and co-brands influence the way men perceive the wearers of shirts. Having a brand of any kind rendered a perception that the wearer was significantly more engaged in the sport. Women's perceptions of sport engagement were more likely to be influenced by fashion brands than by a sportswear brand. Branded and co-branded brands could command higher prices for men but not for women. Women expected to pay less for fashion brands co-branded with a sportswear brand than for a single fashion brand.
Engagement in a sport influences consumer spending in that sport. A study of marketing strategy in the golf industry in the United States and Canada found that American and Canadian market segments were very similar in engagement in golfing, and that broadly similar marketing strategies were successful in both markets [13]. However, when examining the marketing strategy variables more closely, Canadian golf courses seem to provide a better assortment of higher quality products, better brand name golfing products, more golf course options, and special features. They have better reservations systems, hours of operations, guarantees and customer satisfaction policies. The establishment appearance is more attractive, cleaner, and with good parking facilities. The staff is also dressed more professionally in golf attire. Although both regions have similar pricing strategies, Canada offers better value bundling to increase sales. This study demonstrates that a better understanding of a target market can help in the development of better marketing strategies that better appeal to the sport market.

\section{Purpose of the Study}

The successful marketing strategy of sports outfitters requires the identification of a target market and development of a marketing mix (product/service, place, price and promotion) that will best satisfy the needs of this target market. This research was conducted to investigate marketing strategies implemented by sports outfitters and whether there were differences are found in Canada and the United States.

\section{Methodology}

Following a methodology established in recent studies [13-17], this exploratory study, using 20 case studies, was undertaken in the contiguous regions of southwestern Quebec and northern New York/Vermont. There is substantial economic integration and cross-border traffic between the two countries in this region, and the hospitality industry targets business and leisure travelers of both nationalities [18]. For this reason, many similarities have been observed in these studies of the hospitality industry in these two countries.

A census of the sports outfitters in two communities in this cross-border region was included in this research. The online Yellow Pages directory for the United States and Canada was used to identify the sampling frame of sports outfitters in the contiguous geographic regions along the border. The region under study was expanded until 20 establishments were identified, representing the regions as follows: 10 from Quebec and 10 from New York/Vermont. The typical sports outfitter in this study was an independently owned and operated family business that thus controlled its marketing strategy. 
A detailed marketing strategy evaluation grid [13-17] was used to collect detailed qualitative observational descriptions and quantitative data of the sports outfitter marketing strategy variables. Marketing strategy refers to the target market of the establishment and the marketing mix variables designed to attract these customers. The marketing mix variables are categorized according to the popular 4P framework [19] for retailing of goods (Product; Place; Price; and Promotion), and not the 7P framework common for services, although 6 of the 7Ps are captured in the list of variables. Three of these categories of variables are subdivided in this study to capture the breadth of the categories: Product consists of product variety variables and service-related variables; Place refers to the location of the establishment as well as store atmospherics; and Promotion includes advertising variables and personal selling variables. The comparison framework therefore consists of two cultural/geographic regions by 8 marketing variable ratings.
(See table 1).

The observational research was conducted by international marketing students who were familiar with the marketing concepts. Observers received training on a variety of dimensions of the research process. They received a detailed explanation of each of the variables in the Marketing Strategy evaluation grid and how each variable is operationalized. They were shown how to find and approach their assigned sports outfitter, how to record their qualitative observations, and how to determine a quantitative score (on a scale of 1 to 5,5 being superior implementation) for each variable. For example, for breadth of product line, students would look at the assortment of products on the premises and make a judgment on the rating scale as to its appeal to consumers (5 would represent an outstanding assortment, beyond expectations; 3 would represent an average assortment usually found in gift shops; and 1 would be the minimum one would expect.

Table 1. Summary of the Marketing Strategy Variables Evaluation Grid

\section{Marketing Mix (4Ps)}

\section{Product:}

Product variety variables: Breadth of product line, assortment of accompanying products, size variations, quality, private labels/brands, special features, overall evaluation. (6 variables, maximum score of 30 )

Service variables: customer services, customized/standardized, credit cards, empathy, reservations (computerization), hours of operation, guarantees, customer satisfaction (complaint handling), overall evaluation. (8 variables, maximum score of 40 )

\section{Place:}

Location variables: Primary/secondary road (visibility), site evaluation (neamess to target market), outside appearance, private/public parking availability, detached building versus strip, general ease of access, overall evaluation. ( 6 variables, maximum score of 30 )

Establishment atmospherics: Interior layout (free form, grid, racetrack); atmospherics-scent, lighting, color, mirrors, music, noise, signage; fixtures; cleanliness; size of crowds; type of clientele; access to disabled; overall evaluation. (12 variables, maximum score of 60)

\section{Price:}

Pricing variables: Relative high/ow prices, competitive in region, group reductions, coupons/rebates, bundle or value pricing (packages offered), variety of payment options, overall evaluation. (5 variables, maximum score of 25 )

\section{Promotion:}

Advertising variables: Newspapers, magazines, trade publications, television, radio, telemarketing, direct mail, intermet, special promotions (sales, coupons, contests), outdoor ad and/or signage, advertising theme-testimonial, comparison, informative, humorous, etc., overall evaluation. (6 variables, maximum score of 30 )

Personal selling variables: Approa ching the customers, helpfulness, presenting product/service, making the sale, knowledgeable, art of listening, verbal/non-verbal cues, general appearance of staff, overall evaluation. (8 variables, maximum score of 40 )

\section{Summary rating:}

Overall marketing strategy evaluation: addition of the overall rating in the categories. 
The trainer and trainees performed a "walk-through" of the research process prior to visiting the sports outfitters to ensure their understanding and consistent implementation of the data collection. Observation and listening were usually sufficient to gather information about each variable. For example, for the target market, they could look at license plates in the parking lot and see how many cars came from what state or province. They could tell what language, French or English, was spoken by the customers. They could ascertain if they were repeat customers if they appeared familiar with the establishment when they arrived, when they referred to past purchases, or when they were on first name basis with the staff. However, if some variables were difficult to observe, students were given guidelines for asking questions of the staff.

Three trained observers visited each establishment together in both regions, spending 4-5 hours in each location to record detailed notes of how each marketing strategy variable was implemented. Then, the three observers had to discuss and come to an agreement on a score (on a scale of 1 to 5, 5 representing superior implementation of the strategy) for each variable in an attempt to quantify the observational data. Since this process resulted in one rating for each variable, inter-judge reliability measures were not relevant. Each item within a variable category was weighted equally in this research. The data collection thus consisted of qualitative data, the recorded observations, and quantitative data, the assigned scores for each variable.

\section{Findings}

The findings are discussed below in terms of quantitative results and qualitative results. Tables 2 and 3 present the quantitative results of the scale ratings for each of the eight variable categories. Although the sample size is relatively small, T-tests of significance were performed to ascertain where more important differences can be found. Inspection of the table reveals that there are more similarities than differences in marketing strategy variables in the two regions.

\section{Product}

The product strategy scores for the outfitters in both regions are very similar. It is the highest rated marketing strategy variable in the U.S. and the second highest rated variable, after location, in Canada. Closer inspection of Table 3 finds some differences between the two regions on some of the product variables. The Quebec sports outfitters appear to have better product assortments, and offer more brand name products than sports outfitters in Vermont/New York. On the other hand, the U.S. sports outfitters offer significantly more special features such as variety of color selections and accessories.

Table 2. Marketing Strategy Summary for Sports Outfitters

\begin{tabular}{|c|c|c|c|c|c|}
\hline Marketing Strategy Variable Ratings & \multicolumn{2}{|c|}{ Vermont/New York } & \multicolumn{2}{|c|}{ Quebec } & Significance Level \\
\hline & Mean & $\%$ & Mean & Mean Difference \\
\hline Product Variety (30) & 23.4 & $78.0 \%$ & 23.7 & $79.0 \%$ & 0.89 \\
\hline Services (40) & 29.4 & $73.5 \%$ & 29.0 & $72.5 \%$ & 0.86 \\
\hline Location (30) & 22.1 & $73.7 \%$ & 25.1 & $83.7 \%$ & 0.13 \\
\hline Establishment Design(60) & 36.7 & $61.2 \%$ & 40.9 & $68.2 \%$ & 0.23 \\
\hline Pricing (25) & 16.0 & $64.0 \%$ & 13.5 & $54.0 \%$ & 0.79 \\
\hline Promotion (30) & 16.4 & $54.7 \%$ & 17.1 & $57.0 \%$ & 0.98 \\
\hline Personal Selling (40) & 29.3 & $73.3 \%$ & 29.4 & $73.5 \%$ & 0.46 \\
\hline Overall Marketing Strategy & 173.3 & $68.0 \%$ & 178.7 & $70.1 \%$ & 0.75 \\
\hline
\end{tabular}

*Mean: Average of the sum of ratings for all variables in the category.

$* * \%$ : The mean results are represented as a percentage of the maximum score that could be achieved for the variable category. 
Table 3. Comparison of Quebec and New York/Vermont Sports Outfitters on Marketing Strategy Variables Ratings

\begin{tabular}{|c|c|c|c|c|c|c|c|}
\hline \multirow[b]{2}{*}{ Product Variety } & \multicolumn{2}{|c|}{ Overall Sample } & \multicolumn{2}{|c|}{ Vermont/NY } & \multicolumn{2}{|c|}{ Quebec } & \multirow{2}{*}{$\begin{array}{c}\text { Significance } \\
\text { Mean Difference }\end{array}$} \\
\hline & Mean & St.Dev & Mean & St.Dev & Mean & St.Dev & \\
\hline Breadth & 4.40 & 1.05 & 4.40 & 1.35 & 4.40 & 0.70 & 1.00 \\
\hline Assortment & 4.00 & 0.97 & 3.80 & 1.03 & 4.20 & 0.92 & 0.39 \\
\hline Size & 3.75 & 1.29 & 3.90 & 1.29 & 3.60 & 1.35 & 0.59 \\
\hline Quality & 4.20 & 1.06 & 4.10 & 1.29 & 4.30 & 0.82 & 0.66 \\
\hline Brands & 3.55 & 1.47 & 3.30 & 1.83 & 3.80 & 1.03 & 0.47 \\
\hline Features & 3.55 & 1.63 & 3.90 & 1.29 & 2.80 & 1.81 & 0.06 \\
\hline \multicolumn{8}{|l|}{ Services } \\
\hline Services & 3.80 & 1.15 & 3.70 & 1.25 & 3.90 & 1.10 & 0.75 \\
\hline Customization & 3.65 & 1.14 & 3.30 & 1.34 & 4.00 & 0.82 & 0.19 \\
\hline Credit & 4.00 & 1.30 & 4.10 & 1.37 & 3.90 & 1.29 & 0.17 \\
\hline Empathy & 3.65 & 1.23 & 4.00 & 1.15 & 3.30 & 1.25 & 0.23 \\
\hline Reservation & 4.00 & 1.08 & 4.00 & 1.33 & 4.00 & 0.82 & 1.00 \\
\hline Hours & 3.70 & 1.03 & 3.20 & 1.14 & 4.20 & 0.63 & 0.04 \\
\hline Guarantees & 2.90 & 1.45 & 3.30 & 1.49 & 2.50 & 1.35 & 0.12 \\
\hline Satisfaction & 3.40 & 1.19 & 3.60 & 1.43 & 3.20 & 0.92 & 0.34 \\
\hline \multicolumn{8}{|l|}{ Location } \\
\hline Visibility & 4.00 & 1.30 & 3.60 & 1.58 & 4.40 & 0.84 & 0.24 \\
\hline Site & 4.20 & 1.01 & 3.80 & 1.23 & 4.60 & 0.52 & 0.06 \\
\hline Appearance & 3.70 & 0.92 & 3.50 & 1.18 & 3.90 & 0.57 & 0.44 \\
\hline Parking & 3.80 & 1.20 & 4.00 & 0.82 & 3.60 & 1.51 & 0.34 \\
\hline Building & 3.85 & 1.09 & 3.80 & 1.23 & 3.90 & 0.99 & 0.59 \\
\hline Access & 4.00 & 1.26 & 3.40 & 1.43 & 4.60 & 0.70 & 0.03 \\
\hline \multicolumn{8}{|l|}{ Establishment } \\
\hline Layout & 4.25 & 1.12 & 3.90 & 1.45 & 4.60 & 0.52 & 0.24 \\
\hline Scent & 3.40 & 1.54 & 3.40 & 1.58 & 3.40 & 1.58 & 1.00 \\
\hline Light & 3.75 & 1.41 & 3.40 & 1.35 & 4.10 & 1.45 & 0.13 \\
\hline Color & 3.30 & 1.75 & 2.90 & 1.79 & 3.70 & 1.70 & 0.21 \\
\hline Music & 2.55 & 1.39 & 2.50 & 1.51 & 2.60 & 1.35 & 0.86 \\
\hline Noise & 3.40 & 1.43 & 3.10 & 1.52 & 3.70 & 1.34 & 0.26 \\
\hline Signage & 3.00 & 1.59 & 3.00 & 1.70 & 3.00 & 1.56 & 1.00 \\
\hline Fixtures & 3.75 & 1.48 & 3.60 & 1.43 & 3.90 & 1.60 & 0.71 \\
\hline Clean & 3.40 & 1.54 & 3.10 & 1.60 & 3.70 & 1.49 & 0.28 \\
\hline Crowd & 2.90 & 1.62 & 3.10 & 1.73 & 2.70 & 1.57 & 0.53 \\
\hline Clientele & 2.90 & 1.62 & 3.10 & 1.73 & 2.70 & 1.57 & 0.48 \\
\hline Disabled & 2.45 & 1.39 & 2.20 & 1.48 & 2.70 & 1.34 & 0.45 \\
\hline \multicolumn{8}{|l|}{ Pricing } \\
\hline HiLo Pricing & 3.60 & 0.88 & 3.60 & 0.84 & 3.60 & 0.97 & 1.00 \\
\hline Competitive & 3.20 & 1.15 & 3.40 & 1.07 & 3.00 & 1.25 & 0.22 \\
\hline Group Rate & 2.40 & 1.47 & 2.40 & 1.43 & 2.40 & 1.58 & 1.00 \\
\hline Coupons & 2.80 & 1.70 & 3.10 & 1.91 & 2.50 & 1.51 & 0.48 \\
\hline Bundle & 2.75 & 1.59 & 3.50 & 1.72 & 2.00 & 1.05 & 0.06 \\
\hline \multicolumn{8}{|l|}{ Promotion } \\
\hline Print & 2.80 & 1.20 & 2.80 & 1.23 & 2.80 & 1.23 & 1.00 \\
\hline Broadcast & 2.45 & 1.47 & 2.70 & 1.49 & 2.20 & 1.48 & 0.45 \\
\hline Other & 3.10 & 1.45 & 3.10 & 1.20 & 3.10 & 1.27 & 1.00 \\
\hline Promos & 3.40 & 1.27 & 3.30 & 1.34 & 3.50 & 1.27 & 0.74 \\
\hline Outdoor & 2.20 & 1.15 & 1.80 & 1.03 & 2.60 & 1.17 & 0.12 \\
\hline Theme & 2.80 & 1.11 & 2.70 & 1.06 & 2.90 & 1.20 & 0.62 \\
\hline \multicolumn{8}{|l|}{ Personal Selling } \\
\hline Approach & 3.65 & 1.53 & 3.60 & 1.51 & 3.70 & 1.64 & 0.81 \\
\hline Helpful & 4.05 & 1.15 & 4.30 & 0.82 & 3.80 & 1.40 & 0.36 \\
\hline Present & 3.80 & 1.32 & 3.90 & 1.52 & 3.70 & 1.16 & 0.78 \\
\hline Make Sale & 2.85 & 1.39 & 2.90 & 1.45 & 2.80 & 1.40 & 0.82 \\
\hline Knowledge & 4.05 & 1.15 & 4.20 & 1.14 & 3.90 & 1.20 & 0.64 \\
\hline Listening & 3.95 & 1.23 & 3.90 & 1.20 & 4.00 & 1.33 & 0.88 \\
\hline Cues & 1.90 & 1.71 & 2.70 & 1.57 & 3.10 & 1.91 & 0.56 \\
\hline Personal Appearance & 4.00 & 0.92 & 3.80 & 1.03 & 4.20 & 0.79 & 0.10 \\
\hline
\end{tabular}




\section{Service}

Sports outfitters in both regions also perform equally well on retail services. The Vermont/New York sports outfitters offer more payment and credit card financing options than Quebec establishments. They also performed better on supporting their guarantees (e.g., after-sale service) and achieving customer satisfaction with more empathy for their clients. Quebec sports outfitters offer more services, and tend to customize products to the specifications of their customers than their U.S. counterparts. Quebec sports outfitters also have longer and more accommodating hours of operations to meet their clientele's needs.

\section{Location}

The Quebec sports outfitters had much better locations for their establishments than the Vermont/New York stores. They tend to be located on primary roads with high visibility and greater ease of access. They are in high traffic commercial areas that attract a lot of customers. The buildings' exterior appearance has clean and attractive designs. The Vermont/New York establishments generally have their private parking lot with sufficient space for their customers, whereas parking in Quebec is more likely on the street or public parking in a commercial strip mall.

\section{Establishment Design}

In both regions, the store layout was judged to be either free form or racetrack, allowing the customers to explore and roam through the store and be easily exposed to a variety of merchandise. The Quebec stores appear to do it better for most of the establishment design variables. The store layout is more appealing and easier to navigate for the customers. The lighting and color enhance the product offering. The fixtures and gondolas are more attractive. The stores are cleaner and less noisy, and easier to access for the disabled. Both regions are similar with respect to store scent, music selections, and use of signage. Although the American establishments received lower ratings on this variable, there were more customers in these stores at the time of the observations. This may be due to their better performance on the pricing variable.

\section{Price}

The American sports outfitters tend to have better pricing strategies than Canadian establishments. Both regions' prices are in the same price range category and they both cater to sports teams by offering special lower team prices on select product categories. However, the prices in Vermont/New York are more competitive. The stores also offer more value bundling for combinations of products, as well as promotional coupons.

\section{Promotion}

The promotion strategy variable received the lowest rating in the marketing strategy of sports outfitters in both regions.
Establishments in both regions did very little print advertising and internet advertising. The American outfitters did more broadcast advertising while Quebec outfitters did more out-of-home advertising, sales promotions and had better advertising themes in their advertising effort.

\section{Personal Selling}

The personal selling component of promotional strategy received a very good rating in both regions. The sales personnel in both regions were very friendly and approachable. They were knowledgeable about their products and were very helpful to the customers. They were very good at providing information to help customers make their purchase decisions, but they did not push to make the sale. In both regions, the sales personnel's appearance was appropriate for this type of retail establishment. They wore good quality casual sports clothes of the type carried in the store.

\section{Discussion and Implications}

Overall, sports outfitters in Quebec and New York/Vermont appear to implement similar marketing strategies, as indicated in Table 2. In both regions, product/service, personal selling and location strategies receive better ratings than other variables, suggesting that they would appeal to their respective target markets. In both regions, the establishment design, pricing and promotion variables are weaker and could be improved. When examining the breakdown of the $4 \mathrm{P}$ variables into more specific components, the findings may provide guidance for benchmarking as well as areas of improvement in both regions.

Quebec sports outfitters could improve their marketing strategies in a number of ways. They could improve their product strategy by expanding their apparel size offerings (e.g. petite, big \& tall), and they could increase special features such as a wider selection of accessories, high energy snacks and drinks, and so on. They could accept a wider range of credit card options (American Express, Discover) as forms of payment for purchases. They can also provide more support to their guarantees to achieve more customer satisfaction. Their location strategy can be a benchmark for American sports outfitters. For Quebec retail establishments not located in a mall, access to parking could be improved. If there is an underutilized parking area nearby, paying for a few spaces reserved for their customers, with corresponding signage, might increase store traffic, especially when street parking is unavailable. Although establishment design is good compared to US establishments, some improvement can be made in access to the disabled, as well as appropriate music selection. In terms of pricing strategy, Quebec outfitters could provide more value bundling as done in the New York/Vermont stores, for combinations of products purchased. They can consider offering group discounts for 
local sports teams. Promotional coupons can easily be made available online on their website, social media, e-mail, or newspaper ads. A valuable email list may be obtained easily by offering occasional e-coupons or special offers to patrons who give their email address. Another approach to easily obtain a mailing list of customers and prospective customers is to hold a drawing for something substantial (e.g., kayak) at a sporting event in the region, and require e-mail address on the drawing stub/slip. Personal selling strategy is well-developed, but sales associates may need training to "make the sale" without pressuring the customers (e.g. "and will you be needing tennis balls with this new racket?).

New York/Vermont sports outfitters can also benefit from similar improvements in their promotion and personal selling strategies. They can also improve their product strategy by improving their product assortment and offering more brand name products and higher quality products. Their hours of operations can be adjusted to better meet the needs of their clientele. Store locations are not always in high traffic, visible areas, and access from the road is sometimes constrained (e.g. requiring U-turn to access). In such cases, more visible signage can help people find the store. The curb appeal of the establishment is sometimes lacking. Careful cleaning and maintenance of the facilities is important to make the right impression of a successful business. Improvements can be made in the layout to facilitate navigation throughout the store, and easy exposure to a variety of merchandise. Attractive gondolas and fixtures enhance the presentation and showcase the products, making them more appealing. All of these factors may also help improve access to the disabled. Appropriate background music can also enhance the shopping experience. Pricing strategy is very competitive in this region. However, there is an opportunity to offer group discounts for local sports teams to encourage more store patronage.

\section{Conclusion and Future Research}

This exploratory research suggests that sports Outfitters in Quebec and Vermont/New York have well-developed product and service as well as location strategies, showing a good understanding of their target markets' needs and wants. Both also have weaker promotion strategies with respect to advertising, but very good personal selling strategies. The Quebec sports outfitters have better location and establishment design strategies than Vermont/New York establishments, while the latter have better pricing strategies. These findings are helpful to sports outfitters in that they identify which variables are well implemented, and provide direction for improvements in their respective strategies.

This study only examined one province in Canada and two states in the U.S. More research is needed in other parts of these two countries to see if these findings apply. In addition, a more quantitative approach to determine different market segments' preferences for different strategy variables, and determination of their reaction to different elements of the marketing strategy would be recommended for future research.

\section{REFERENCES}

[1] K. G. Jones, M. J. Doucet (2001). The big box, the flagship, and beyond: Impacts and trends in the greater Toronto area, Canadian Geographer, Vol. 45, No. 4, 494-512, 2001.

[2] B. Borzykowski. Win big with sporting goods, Canadian Business, Vol. 86, No. 5, 33-34, 2013.

[3] Forbes. Factors affecting our \$74 valuation of Under Armour, 2014. Online available from http://onforb.es/OSPx8F

[4] K. Gold. In the bag, Marketing, Vol. 118, No. 14, 42-44, 2013.

[5] M. Hurst.Who participates in Apactive leisure? Statistics Canada, Canadian Social Trends, 11-008-X, No. 87, 2009. Retrieved May 22, 2015.

[6] Statistics Canada. Sport participation in Canada. Culture, Tourism and the Center for Education Statistics, 81-595-M, No. 060, 2005. Retrieved May 22, 2015.

[7] A. Richelieu. (2013). Strategic management of the brand in the world of sport, Journal of Brand Strategy, Vol. 2, No. 4, 403-415, 2013.

[8] A. J. Rohm, G. R. Milne, M. A. McDonald (2006). A mixed-method approach for developing market segmentation typologies in the sports industry, Sport Marketing Quarterly, Vol. 15, No. 1, 29-39, 2006.

[9] E. Ko, C. R. Taylor, H. Sung, Y. Lee, U. Wagner, D. Martin-Consuegra Navarro, F. Wang. Global marketing segmentation usefulness in the sportswear industry, Journal of Business Research, Vol. 65, No. 11, 1565-1575, 2012.

[10] S. D. Ross. Segmenting sports fans using brand associations: A cluster analysis, Sports Marketing Quarterly, Vol. 16, No. 1, 15-24, 2007

[11] V. D. Bush, A. J. Bush, K. J. Shannahan, R. J. Dupuis. Segmenting markets based on sports orientation: An investigation of gender, race and behavioral intentions, Marketing Management Journal, Vol. 17, No. 1, 39-50, 2007.

[12] D. J. Wu, L. Chalip. Expected price and user image for branded and co-branded sports apparel, Sports Marketing Quarterly, Vol. 22, No. 3, 138-151, 2013

[13] L. Heroux, Lise. Marketing strategies of golf courses in the United States and Canada: A comparative exploratory study, Proceedings of the Eurasia Business Research Conference, World Business Institute, Istanbul, Turkey, June, 2015.

[14] L. Heroux. Restaurant marketing strategies in the United States and Canada: A comparative study, Journal of Foodservice Business Research, Vol. 5, No. 4, 95-110, 2002.

[15] L. Heroux, J. Csipak. Comparative marketing strategies of motels in Canada and the United States: An exploratory study, Proceedings of the Administrative Sciences Association of Canada Conference, L. Heroux, ed., London, Ontario, Vol. 22, No. 23, 35-44, 2001.

[16] L. Heroux, J. Csipak. Marketing strategies of bars in the 
United States and Canada: A comparative exploratory study, Journal of Foodservice Business Research, Vol. 8, No. 2, 55-72, 2005.

[17] L. Heroux, L. Burns. Comparative marketing strategies of bed-and-breakfasts in Canada and the United States: An exploratory study, Proceedings of the Administrative Sciences Association of Canada Conference, N. J. Church, ed., Vol. 21, No. 23, 21-28, 2000.
[18] N. J. Church, L. Heroux. Canadian and American travellers: Fraternal twins? An exploratory study of hotel macro-choice criteria, Proceedings of the Administrative Sciences Association of Canada Conference, C. Ralston, ed. Saint John, New Brunswick, Vol. 20, No. 23, 22-30, 1999.

[19] J. E. McCarthy, W. D. Perreault. Essentials of Marketing, $8^{\text {th }}$ Edition, Irwin, 2000. 